Phenomenology \& Practice, Volume 12 (2018), No. 2, pp. 1-4.

\title{
Editorial
}

\section{Lingis Special Issue: Travel as the Possibility of Being Brought Back to Ourselves}

\author{
Patrick Howard, Cape Breton University \\ PatrickHoward@,cbu.ca
}

Tone Saevi, NLA University College Bergen, Norway

Tone.Saevi@,nla.no

The existential philosopher Albert Camus (1998) wrote, "What gives value to travel is fear" (p. 180). Camus continues by describing a moment while travelling when we are "seized by a vague fear" and yearn for the security of the familiar, "the protection of old habits" as Camus puts it. Authentic travel is disruptive, anything but a pleasurable distraction, because it potentially lays us bare, and in doing so says Camus, "brings us back to ourselves." In this special issue of Phenomenology \& Practice we make time and space to explore the work of Alphonso Lingis. Professor Lingis has been described as the "itinerant philosopher" (George \& Sparrow, 2014). By way of his wide and varied travels, Lingis unsettles. His subjects, the people, places, creatures, events, ceremonies, and rituals are at once expansive, ethereal, sensual, unique, and challenging. Lingis's style is unpredictable, chapters and topics at times seemingly disconnected, a trek through the exotic and the everyday at the same time. But his is an experiential pilgrimage across a topography of human relations and cultures, an embrace of all that we may encounter in socially and biologically diverse communities of others both human and more -than- human.

Lingis's work has the capacity to bring us face to face with material subjectivity, a vitalism that can disarm and in Camus's words, "bring us back to ourselves." Lingis does so with a phenomenological sensitivity for the life of the other. In this age of instrumental rationalism, those of us who spend our careers in fields associated with the human sciences whether it be pedagogy, nursing, medicine, other health related disciplines, social work, and counseling psychology often struggle to maintain an orientation of phenomenological sensitivity to the lived experience of the other. The familiarization of categories and constructs, the domestication of the visceral, and the lived by abstraction and generalizability takes us away from the messiness of the unique, the individual, the meeting of human beings where they are in their worlds. Lingis bids us to join him on his journeys that unsettle certitude and truths which crumble in face of difference. He brings us back to ourselves by exploring the complexity of his relation to otherness in an attitude of fear-less possibility in the discovery of alterity in its many forms and earthly manifestations. 
Lingis invites us into a way of being that runs counter to the vicarious, virtual, digitized experiences through which our lives are most often mediated today. As professionals, we are often told to sublimate the embodied and the sensual in favour of a functional rationality opposed to sensuous feeling. However, Lingis embraces embodiment in constituting our knowledge and experience of the world. In his writing, Lingis grounds us firmly within a perceptible world in which we are immersed and through which ethical appeals are communicated to us. It is in this sense that Lingis's imperative comes into being. We are called to be travellers, and as travellers we both fear and delight in the possibilities of having our world open wide - transformed. It is the contingency of life, the unknown, the unpredictable and serendipitous that holds us tenuously between the safety of the familiar and the free-flowing fear of the encounter with the alien, the strange, the other.

Lingis lives in this liminal space, the spaces between. There is risk and dis-quiet in decentering the self and being truly open to the otherness of the other. This is the ethical encounter - not a prescriptive, but a pure ethics stemming from a meaningful sensitivity for the life of the other, and the responsibility for the other that addresses us uniquely and individually. These are travels we may take with great trepidation, but the value in these journeys is immense.

Professor Lingis's contribution to this special issue is a provocative journey into the ineffable and unsettling phenomenon of risk, fate, luck, chance, and choice. Our embodied consciousness is susceptible to a myriad of signals and demands, not the least of which is chance. However, says Lingis, chance is a phenomenon for which "in the West there is no longer a reputable discourse ...; it only survives in the marginalized talk of gamblers and fortunetellers." Lingis is responding to this perceived gap by providing in true Lingisian fashion by grounding the most ineffable of human experiences - happenstance, coincidence, serendipity, and fate - in visceral narratives in which the mysteriousness of chance is inscribed on the bodies and minds of people and dwells there as a vital, powerful substratum of all life.

Stephen Smith takes up Lingis's notion of community and the understanding that ultimately, we all belong to a community that in essence "has nothing in common." This "nothing" being that which cannot be subscribed to any direct source outside the forces and passions out of which our bodies and all life emerges. Smith makes use of Alphonso Lingis's groundbreaking work Community of Those Who Have Nothing in Common and Lingis's animal writings to explore symbiotic relations and bodily kinship with domesticated animals. The forces that organize life are common to the community of life, and we cannot hope to assimilate or truly domesticate it. Smith uses fear and the significance of predatory threats and the "protectionist responses they occasion" to demonstrate the claims made upon on us by the vital forces defy assimilation and domestication in both the human and the non-human so that life will not be autonomized but draw from the sensuous materiality on which we are nourished.

Patrick Howard starts his article with an old riddle discussed between himself and his older brother when they both were children,

"If a tree falls in the forest does it make a sound?"

"Of course," I thought. I imagined an ancient spruce crashing to the forest floor in spectacular fashion. "The answer is so obvious; how can this even be a riddle?"

"Yes, but what if there's no one around to hear it," my brother explained, "Does it still make a sound then?" 
"Well, the animals would hear it."

"They don't matter; it has to be a person," my brother countered.

"Why?"

"Because animals can't tell you if the tree makes a sound; only people can. And if there's no people, there's no sound!"

Howard uses Lingis's essay "The Murmur of the World" to reflect on the perennial existential questions of for whom does nature exist and through whose perspective does nature move, speak, and act. "The fundamental understanding of the world at the heart of the puzzle creates a chasm, an extreme sociological and scientific reductionism that becomes distressingly apparent in characterizing how humans relate to the non-human world," Howard suggests. Sounds hold identity, duration, lifespan, and complex patterns of change. An orientation toward sound facilitates an innovative listening and produces a world whereby the auditory self is part of a sonorous, reciprocal intersubjectivity. This, Howard says, has pedagogical implications. Adorno's concepts of non-identity and negative dialects and Lingis' distinction between rationalist abstract thinking and the awareness of the "other" as communication within communication are both orientations that address the playful search for meaning beyond abstract meaning and question our satisfaction with plain concepts. By doing so, Howard opens the human community to the multitudes of expressive more-than-human others.

Alphonso Lingis and Tone Saevi in Conversation cover several seemingly disruptive and disconnected topics and perspectives. Professor Lingis tells of people he met, significant encounters with vulnerable persons that more often than not suffer difficult fates. He does not often give advice on a direct question of what phenomenologists today should write about, but responds, "If you think that this topic is important enough for you to spend several years of the best years of your life on, then you must think it's important for other people. Consequently, it's urgent for you to write in such a way that you communicate, instead of just writing in such a way that people think that you are profound because what you write is obscure." Professor Lingis urges us to stay close to human culture and human concerns, to stay away from narrow and often benefit-based research, and address ordinary human life experiences of happiness, dependency, grief, chance, and gratitude. This, in his view, is what we as phenomenologists should do.

Michael Emme provides an insightful review of Alphonso Lingis's Wonders Seen in Forsaken Places: On Photography and the Photographs of Mark Cohen. Emme finds repeatedly that each encounter with the entries is disturbing and sets out to understand why. Emme writes, "Both Cohen's photographic art and Lingis' curatorial and written framing of it produce experiences akin to an unsolicited approach, where a stranger intrudes into space, passing too close, but then moving on." The book presents itself in way that solicits both a defensiveness and an ethical responsibility. Emme provocatively concludes that the book proposes an encounter with the photography of Mark Cohen however, the experience for him was characterized as much by his encounter with Alphonso Lingis.

We are pleased to present this special issue of Phenomenology and Practice that explores the work of Alphonso Lingis who challenges and disrupts. We invite you to consider how Lingis's work illuminates different worlds and realities. He explores predominant themes of 
subjectivity, perception, imperative, alterity, embodiment, death, and justice to thereby speaks across many professional fields and practices.

\section{References}

Camus, A. (1998). Notebooks; 1932-1945. (P. Thody, Trans.). New York: Marlow Publishing.

George, B. \& Sparrow T. (2014) The Itinerant Philosopher: On Alphonso Lingis. New York: Punctum Books. 